
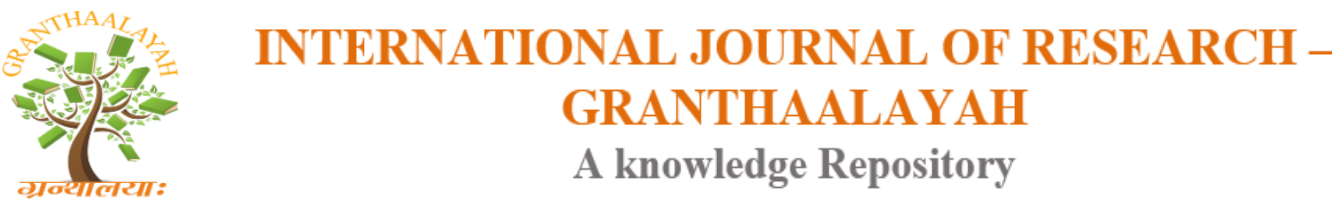

Science

A knowledge Repository

\title{
VALORIZATION OF SUPERABSORBENT POLYMERS FROM USED DISPOSABLE DIAPERS AS SOIL MOISTURE RETAINER
}

\author{
Raymundo Sánchez-Orozco ${ }^{*}$, Beatriz Timoteo-Cruz ${ }^{2}$, Teresa Torres-Blancas ${ }^{3}$, Fernando \\ Ureña-Núñez ${ }^{4}$ \\ *1,2 Laboratorio de Química Aplicada, Tecnológico de Estudios Superiores de Jocotitlán, \\ Jocotitlán, Estado de México C.P. 50700, México \\ ${ }^{3}$ Centro Conjunto de Investigación en Química Sustentable UAEMéx-UNAM, Instituto de \\ Química, Universidad Nacional Autónoma de México, Toluca, Estado de México C.P. 50200, \\ México \\ ${ }^{4}$ Instituto Nacional de Investigaciones Nucleares, Ocoyoacac, Estado de México C.P. 52750, \\ México
}

DOI: https://doi.org/10.29121/granthaalayah.v5.i4.2017.1800

\begin{abstract}
This study was conducted to explore the potential of superabsorbent polymers (SAPs) from used disposable diapers as soil moisture retainer. Swelling behavior of the proposed hydrogel in response to external stimuli such as salt solutions, temperature and $\mathrm{pH}$ was studied. In addition, laboratory experiments were carried out to evaluate the effects of incorporation hydrogel on germination of bean (Phaseolus vulgaris L.) and pumpkin (C. pepo) seeds. The structure of the used superabsorbent was characterized by Fourier transform infrared spectroscopy (FTIR). The

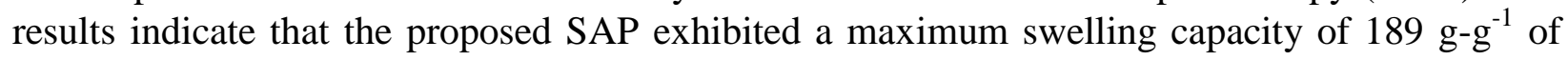
dry gel. It was observed that the swelling capacity decreased with an increase in the ionic strength of the swelling medium. When this SAP was mixed with sandy soil, the mixture was able to lose water more slowly. The seeds germination and seedling growth was remarkably influenced by the application of $0.5,1.0$ and $2.0 \mathrm{w} / \mathrm{w} \%$ of SAP compared to the untreated soil. Therefore, it follows that it is possible to take advantage of SAPs property from used disposable diapers to retain the moisture in soil as an alternative to value the use of such waste, showing that it has potential for agricultural applications.
\end{abstract}

Keywords: Disposable Diaper; Soil Moisture; Swelling Capacity; Used Superabsorbent Polymer.

Cite This Article: Raymundo Sánchez-Orozco, Beatriz Timoteo-Cruz, Teresa Torres-Blancas, and Fernando Ureña-Núñez. (2017). "VALORIZATION OF SUPERABSORBENT POLYMERS FROM USED DISPOSABLE DIAPERS AS SOIL MOISTURE RETAINER." International Journal of Research - Granthaalayah, 5(4), 105-117. https://doi.org/10.29121/granthaalayah.v5.i4.2017.1800. 


\section{Introduction}

One of the most alarming problems in the world today is waste management. The generation and disposal of waste is an intrinsic part of any developing society. A major problem in urban areas is the generation of solid waste including used disposable diapers. These items facilitate human life, but their life span is very short and the manufacturers do not anticipate its disposal; they are simply deposited in landfills, causing serious environmental pollution problems (Cordella et al., 2015). Nowadays, it is estimated that $90-95 \%$ of diapers used in developed countries are disposable (Kosemund et al., 2009). SEMARNAT (2012a) reported that the total waste generation in Mexico increased from 31.4 million tons in 2001 to 42.1 million tons in 2012, a $25.4 \%$ increase in 11 years at a growth rate of $2.3 \%$.

In Mexico the composition of waste generated yearly is mostly organic matter (38\%) and potentially recyclable materials (40\%) (SEMARNAT, 2012b; Espinosa-Valdemar et al., 2014). According to Espinosa-Valdemar et al. (2011), diapers accounted for $6 \%$ of urban solid waste generated in Mexico in 1997, now this amount has increased up to 15\%. The typical composition of a disposable baby diaper has been described by EDANA (2008) and $\mathrm{Ng}$ et al. (2012): fluff pulp $36.6 \%$, SAP $30.7 \%$, polypropylene $6.2 \%$, low density polyethylene $16 \%$, tape, elastic and adhesive $10.5 \%$. Disposable diapers are often seen as being a major problem, however, they can also be treated as a valuable partially biodegradable resource that can be recovered. Recycling of its organic content is an attractive option both, as a resource and waste management strategy (Sannino et al., 2009). At present, used diapers are generally not collected separately and are disposed of as solid municipal waste for further treatment, mainly by incineration, land filling (Mirabella et al., 2013) and, to a lesser degree, by composting (Colón et al., 2013) or anaerobic digestion (Torrijos et al., 2014).

Waste recycling is an important aspect of environment sustainability, on the other hand, minimizes waste products placed in landfills, promotes recovery of materials that can be reused in new productive cycles, prevents energy usage and consumption of fresh raw materials and allows to preserve natural resources and the environment for future generations. A method has been patented for the separating products such as disposable diapers containing superabsorbent polymers into their constituent parts, including a plastic component, super absorbent polymers, and cellulosic fibers, and further refinement of said constituent parts (Grimes, 2012). Biological treatments that valorize the cellulose content of used diapers, such as composting, and use as substrate in edible mushroom production have been investigated at laboratory (Colón et al., 2010, Colón et al., 2013; Espinosa-Valdemar et al., 2015). Valorization of diapers as substrate in cultivation of P. ostreatus of used baby diapers and wheat straw was carried out by EspinosaValdemar et al. (2011).

Because of this, the need arises to propose strategies to mitigate the accumulation of disposable diapers, through the recovery and use of the superabsorbent polymer in conserving soil moisture. Recently, the diverse applications of superabsorbent polymers are still being expanded to many fields including agriculture and sealing composites, horticulture, drilling fluid additives, artificial snow, medicine, and so on (Rosa and Casquilho, 2012). Superabsorbents have been used to help conserve water in a variety of agriculture and horticultural applications (Guilherme et al., 2015; Senna et al., 2015; Qiao et al., 2016). The use of SAP for stabilizing soil structure resulted in 
increasing infiltration and reducing water use and soil erosion (Gao et al., 2013; Essawy et al., 2016). A major advantage of using SAP is its ability to make use of moisture present in soil such as clay, and make it available to the roots. SAP amended soils have better nutrient release, high nitrification, reduced microflora and bacterial content (Demitri et al., 2013; Eneji et al., 2013).

Hence, the aim of this study was to investigate the potential of superabsorbent polymers from used disposable diapers, an abundantly available solid waste, as a nonconventional soil moisture conditioner. The effects of ionic strength, temperature, and $\mathrm{pH}$ of the external solution on the swelling capability were investigated. The use of the hydrogel for the cultivation of bean and pumpkin was also investigated at laboratory conditions.

\section{Materials and Methods}

\subsection{Hydrogel Recovery}

The wet disposable diapers were collected from the local nursery house in Ixtlahuaca - EM, Mexico. Collected disposable diapers only contained liquid waste (i.e. human urine). The diapers were first heat-inactivated by autoclaving at $125{ }^{\circ} \mathrm{C}$ for 15 minutes to eliminate pathogens. After sterilizing, the diapers were chopped up and the components were separated in two parts: cellulose and plastic. The superabsorbent polymer particles intermingled with cellulose fibers were oven dried at $60{ }^{\circ} \mathrm{C}$ for $24 \mathrm{~h}$. The dried hydrogel was retrieved by gently shaking the cellulose fibers in a plastic container in order to freeing the particles from the surrounding. Then, it was ground and sifted with an 80-mesh sieve. Resulting superabsorbent polymer powder was kept in desiccator for further use in moisture retention and soil amendment studies.

\subsection{Measurement of Swelling Ratio}

Dried hydrogel was used to determine the swelling ratio; an accurately weighed sample $(0.1 \mathrm{~g})$ was transferred to a tea bag with fine meshes (nylon screen) and then immersed entirely in distilled water $(100 \mathrm{~mL})$ at room temperature $\left(20{ }^{\circ} \mathrm{C} \pm 2\right)$. At regular time-intervals, the bag was taken out from the solution, the excess of water was wiped superficially with filter paper to remove surface-bound water and the bag was weighted. The same procedure was applied to measure the effect of temperature on the swelling equilibrium in the range of temperatures between $25-50{ }^{\circ} \mathrm{C}$. The swelling ratio (Q) was obtained gravimetrically (Eq. 1):

$$
Q=\frac{W_{s}-W_{d}}{W_{d}}
$$

where $W_{d}$ and $W_{s}$ are the mass of the dry and swollen hydrogels, respectively.

\subsection{Salt Solution Absorbency Measurements}

The swelling properties of the used SAP at different ionic strength were also performed. Hydrogels were immersed in $\mathrm{NaCl}, \mathrm{Ca}\left(\mathrm{NO}_{3}\right)_{2}$ and $\mathrm{CaCl}_{2}$ solutions between 0 and $2.5 \mathrm{wt} \%$ concentrations to observe the swelling equilibrium at room temperature $\left(20{ }^{\circ} \mathrm{C} \pm 2\right)$. The 
determination of water absorbency of superabsorbent polymer in different saline solutions was similar to that in distilled water.

\subsection{Effect of pH on Swelling Ratios of Used Hydrogels}

The effect of $\mathrm{pH}$ on the equilibrium swelling ratio of the hydrogel was determined in buffer media of varying $\mathrm{pH}$, ranging from 2 to 12 . The measurement of water absorbency of superabsorbent in different $\mathrm{pH}$ solutions at room temperature $\left(20{ }^{\circ} \mathrm{C} \pm 2\right)$ was according to the earlier method described for swelling measurement in distilled water. Swelling capacity of the hydrogel at each $\mathrm{pH}$ was measured according to equation (1).

\subsection{Characterization of the Superabsorbent Polymer}

The FTIR spectra of the used SAP were performed on a Perkin-Elmer Spectrum Two FourierTransform Infrared Spectrophotometer under ambient conditions. Attenuated Total Reflection (ATR) mode was used. The spectral scanned range was $4000-500 \mathrm{~cm}^{-1}$.

\subsection{Water Retention Capacity in Soil with Used SAP}

The intention of this test was to assess the effect of the hydrogel amendment on the moisture release curve of a sandy soil. The soil used in this study was taken from an agricultural area of the Ixtlahuaca region - EM, Mexico, characterized by intense vegetable production. The sample were air dried, sieved through a $2 \mathrm{~mm}$ sieve and oven dried at $70{ }^{\circ} \mathrm{C}$ for $24 \mathrm{~h}$. Moisture release curves of soil $(50 \mathrm{~g})$ amended with different amounts of used SAP $(0.5,1$ and $2 \mathrm{wt} \%)$ were evaluated. The soil without the amendment of the superabsorbent polymer was used as a control. Then, the mixtures were uniformly irrigated with $25 \mathrm{~mL}$ of distilled water and exposed at room temperature $\left(20{ }^{\circ} \mathrm{C} \pm 2\right)$. For each mixture, three replications were performed. These mixtures were weighed at certain intervals of time and the weight loss by water evaporation was registered. The water retention (WR) percentage of the soil with or without the hydrogel was calculated by the following formula (Eq. 2):

$$
W R(\%)=\frac{W_{o}-W_{t}}{W_{t}} \times 100
$$

where $W_{o}$ and $W_{\mathrm{t}}$ are the initial mixture weight, and the mixture weight at a certain time, respectively.

\subsection{Effects of Used Hydrogel on Germination Seeds}

The purpose of this study was to explore the possible application of used SAP as water reservoir in agriculture, its direct effect on the cultivation of bean (Phaseolus vulgaris L.) and pumpkin ( $C$. pepo) obtained from a commercial tree nursery in Ixtlahuaca - EM, Mexico, which were used in the essays applied in lab conditions (Hong and Lee, 2016). These species were chosen because they are grown in almost all Mexican territory, are found in a large range of ecological conditions and have economic importance, moreover they may be grown and consumed locally. These seedlings establish best in soils with adequate moisture. The used SAP was mixed at the 
rate of $0.5,1$ and $2 \%$ in dried soil. Then, $200 \mathrm{~g}$ of each of the sandy soil mixtures were filled in plastic pots (300 $\mathrm{mL}$ volume) with a filter paper placed at the bottom with a small hole. The sandy soil without the amendment of the hydrogel was used as a control. Four seeds each of bean and pumpkin were sown in triplicate pots for each of the soil and hydrogel combinations were used. The pots were then placed in plastic trays containing tap water at a depth of $6 \mathrm{~cm}$ and watered to ensure saturation. All the pots were placed in a dark room at the constant temperature $\left(25^{\circ} \mathrm{C}\right)$.

After two weeks, germinated seeds were counted and recorded. Emergence of shoot was taken as an indicator of seed germination. No water was applied except the initial saturation of the pots. When there was evidence of wilting of seedlings appeared for the first time, the experiment was completed. The entire plant shoots and roots were then harvested and the shoot length was recorded, as well as fresh weight and dry weight. The germination percentage (GP) of the seeds was calculated as (Eq. 3):

$$
G P(\%)=\frac{\text { Amount of germination seeds }}{\text { Total seeds }} \times 100
$$

\section{Results and Discussions}

\subsection{Swelling Behavior of the Used SAP}

Absorption capacity in grams of distilled water per gram of dry used superabsorbent polymer at different time intervals was measured. Initially, the rate of water uptake is very fast, and then it begins to level off. As observed in Figure 1, the swelling ability of the used hydrogel reaches its maximum value at $189 \mathrm{~g} \cdot \mathrm{g}^{-1}$ in approximately $30 \mathrm{~min}$. A time length of 30 minutes was thus considered as a reasonable and acceptable duration for complete hydrogel swelling, taking into account the possibilities of its applications in the agricultural field. According to the above results, may be attributed to the fact that superabsorbent polymer possess many hydrophilic groups, appropriate crosslinking degree and convenient three-dimensional network structure which generates osmotic pressure (Gao et al., 2013).

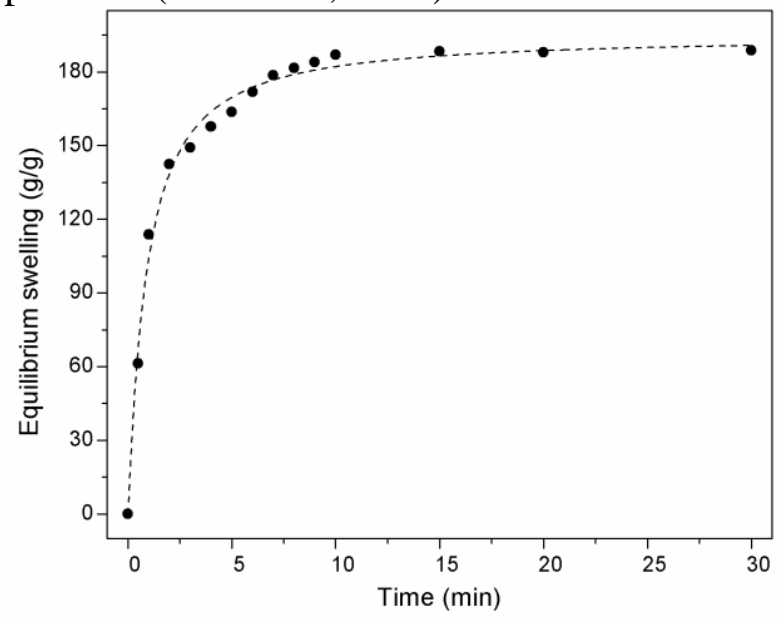

Figure 1: Swelling ratio as function of time for used SAP at room temperature 


\subsection{Effect of pH on Swelling Ratios of Hydrogels}

The $\mathrm{pH}$ sensitivity of SAP polymer was studied by observing the equilibrium swelling (ultimate water absorption) at various $\mathrm{pH}$ values by using buffer solutions (Figure 2). In acidic media, the most of carboxylate groups are protonated. This causes a decrease repulsion of anionic groups, which leads to a decrease in swelling ratio. In acidic condition, the carboxylic groups of the used SAP are protonated, causing a decrease in the repulsion of anionic groups and also a decrease in the swelling ratio. In neutral medium, the ionic strength is smaller than that in basic media, so provides higher swelling capacity (Gawande and Mungray, 2015). This is because the superabsorbent is anionic-type superabsorbent polymer, which contain a majority of hydrophilic groups, and which play an important role in swelling behavior and result in water absorbency changes through different interaction species in various $\mathrm{pH}$ solution. When the $\mathrm{pH}$ is 12 , the increase in the ionic strength of the swelling medium causes the rapid decrease of the ionic osmotic pressure, also promoting the reduction in swelling ability in the equilibrium. It is important to indicate that the hydrogel can promote high swelling capacity at $\mathrm{pH}<10$, which is caused by the buffer action of $-\mathrm{COOH}$ and - $\mathrm{COO}$ - groups and this is a great advantage for the application of superabsorbent in agricultural fields. Similar conclusions could also be found in other works (Cheng et al., 2015).

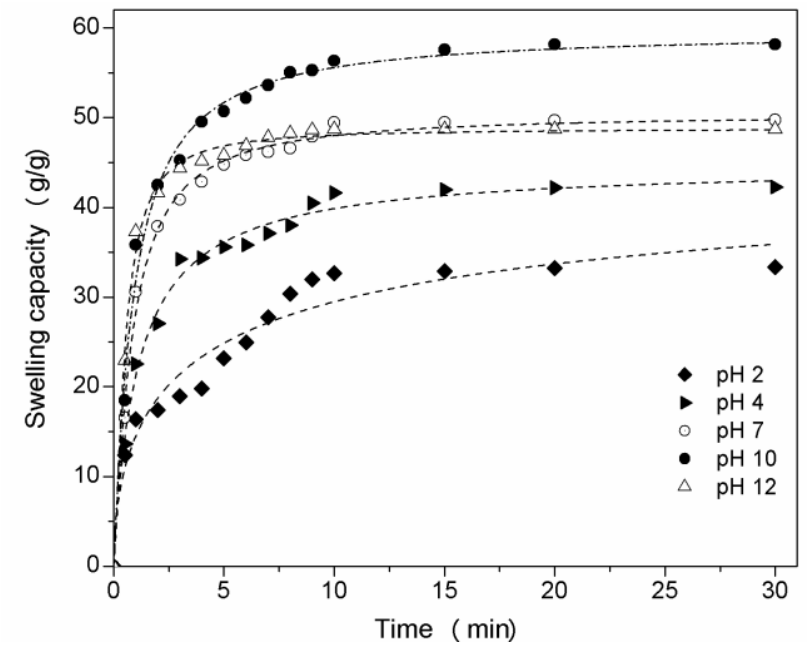

Figure 2: Water retention capacity at different values of $\mathrm{pH}$

\subsection{Effect of Salt Solution on the Swelling Ratio of Used Hydrogel}

It is more important to know the swelling capacity of a superabsorbent polymer when it contacts with various saline solutions considering its practical applications such as water release systems in agriculture. The equilibrium swelling of used SAP in different concentrations of $\mathrm{NaCl}$, $\mathrm{Ca}\left(\mathrm{NO}_{3}\right)_{2}$ and $\mathrm{CaCl}_{2}$ were investigated, as shown in Figure 3. When the SAP is placed in water, the maximum osmotic pressure is developed, and then the maximum swelling is achieved. The swelling ability of the superabsorbent in the three salts in aqueous medium was significantly decreased compared to the values measured in distilled water. This behavior, frequently observed in the swelling of all ionic hydrogels, can be attributed to a screening effect of the additional cations causing a non-efficient anion-anion electrostatic repulsion. This is also associated to a decreased osmotic pressure difference between the SAP network and the external solution resulting from the difference in the mobile ion concentration between the gel and aqueous phases 
decrease and, consequently, the absorbency amounts are diminished. This finding is consistent with previous studies (Li et al., 2015), the decrease in swelling is strongly dependent on the type and concentration of salt added to the swelling medium.

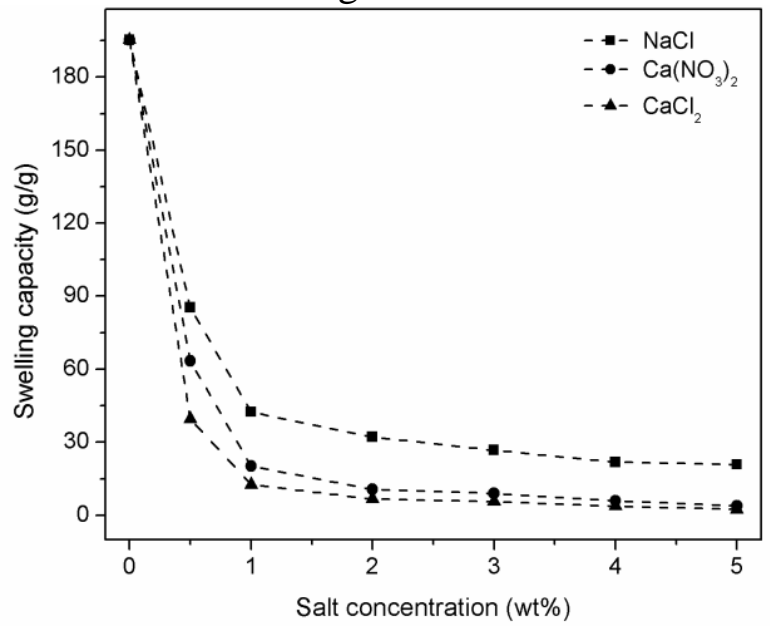

Figure 3: Swelling ratios of superabsorbent in different saline solutions

\subsection{Effect of Temperature on Swelling Ratio of Used Hydrogel}

The effect of environmental temperature on equilibrium swelling of SAP was determined in the range of temperatures between $25-50{ }^{\circ} \mathrm{C}$. Hydrogel exhibits significant continuous changes in water content as a function of temperature (Zhang et al., 2015). It can be seen from Figure 4, the swelling ratio increase with temperature.

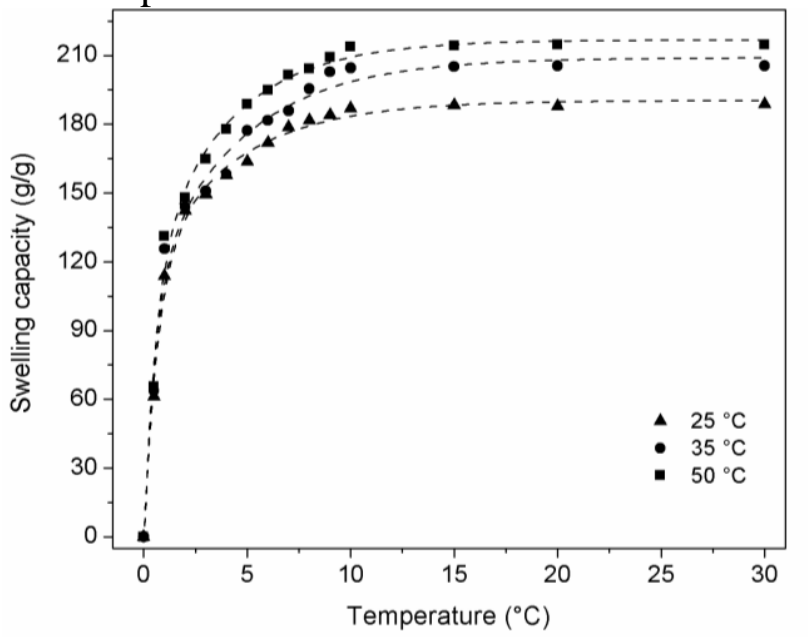

Figure 4: Water uptake capacity as a function of temperature

The results given in Figure 4 can be explained by the fact that at $50{ }^{\circ} \mathrm{C}$ it is thermally more favorable for water molecules to form hydrogen bonds with polar groups in the SAP chains, allowing the hydrogel to exhibit maximum swellability. The results indicate that the swelling ratio increases with increasing temperature. In this connection, it must be pointed out that increasing temperature from 25 to $50{ }^{\circ} \mathrm{C}$, the water absorption capacity increases significantly due to an increase in the segmental mobility of the hydrogel chains. At above $50{ }^{\circ} \mathrm{C}$ the swelling is drastically reduced. Therefore, the decrease in swelling capacity is induced by the breakdown 
of the hydrogen bonds between the water molecules and the chains of the three-dimensional hydrogel network.

\subsection{FTIR Analysis}

The infrared spectroscopy was used to determine the type of bonds present in the used SAP as shown in Figure 5. In the spectra, absorption peaks characteristic of the expected functional groups are visible, in general agreement with published data (Rosa and Casquilho, 2012; Senna et al., 2015; Qiao et al., 2016). The broad absorption band at $3260 \mathrm{~cm}^{-1}$ is ascribed to hydrogen bond $-\mathrm{OH}$ stretching vibration. It can be observed that the medium absorption peak at $2932 \mathrm{~cm}^{-1}$ represents symmetric and asymmetric $\mathrm{C}-\mathrm{H}$ stretching vibration of aliphatic structures. The peak at $1402 \mathrm{~cm}^{-1}$ was due to bending vibration of $\mathrm{C}-\mathrm{H}$ of methyl group. The absorption bands at 1552 and $1052 \mathrm{~cm}^{-1}$ are attributed to the appearance of $-\mathrm{C}=\mathrm{O}$ of bonded conjugated ketones, carboxylic acids and esters. Based on the above analysis, the presence of various functional groups suggests that the employed SAP could have the possibility to be used as a soil amendment for improving moisture.

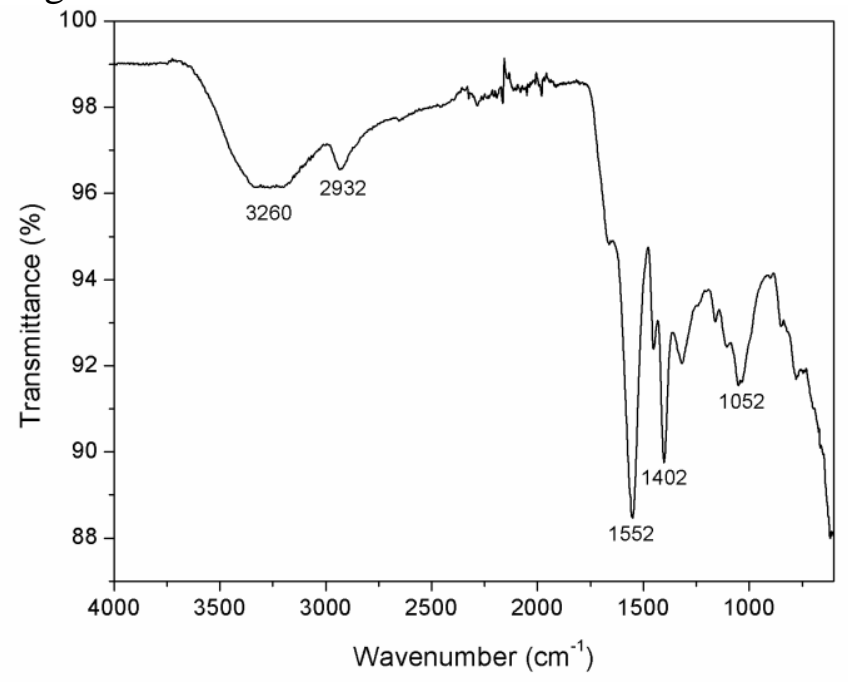

Figure 5: FTIR of used superabsorbent polymer

\subsection{Water Retention Behavior in Soil-Superabsorbent Polymer}

For agricultural use it is essential to evaluate the ability of the superabsorbent polymer to retain water in the soil for vegetation growth. Liquid water ensures the feeding of plants with nutritional elements, which increases the growth quality of plants. Figure 6 shows the water retention of soil mixed with SAP and soil without the SAP. The percentage of water retained by the soil, monitored for several days after an initial irrigation of a soil sample with different amounts of hidrogel was indeed significantly affected by the presence of the hydrogel, with higher water contents detected at selected time points, when increasing the hydrogel concentration. The rate of water loss increased with increased incubation time. The value of $100 \%$ corresponds to the initial weight of soil-hidrogel-water mixtures. It can be observed from Figure 6 that the amount of water in the control soil (without SAP) reaches zero after 12 days. After the addition of small hydrogel amounts (up to a maximum of $2 \%$ ), the time length through which the soil remained humid almost triplicated, with respect to the soil without hydrogel. It is 
clear that soil mixed with SAP can hold more water than soil without SAP. When soil is treated with SAP, its water retention properties are related to both porosity and the SAP's water absorbency. These results suggested that the adding of hydrogels into soil could obviously improve the water-retention capacity of soil and lessen the amount of water evaporation (Li et al., 2015; Liao et al., 2016). The trends of the curves suggest that the SAP improved the water retention properties of the treated soil during the early period. Similar effects of hydrogels on loamy soil water holding properties by Akhter et al. (2004), and in sandy soils by Dorraji et al. (2010) have been investigated.

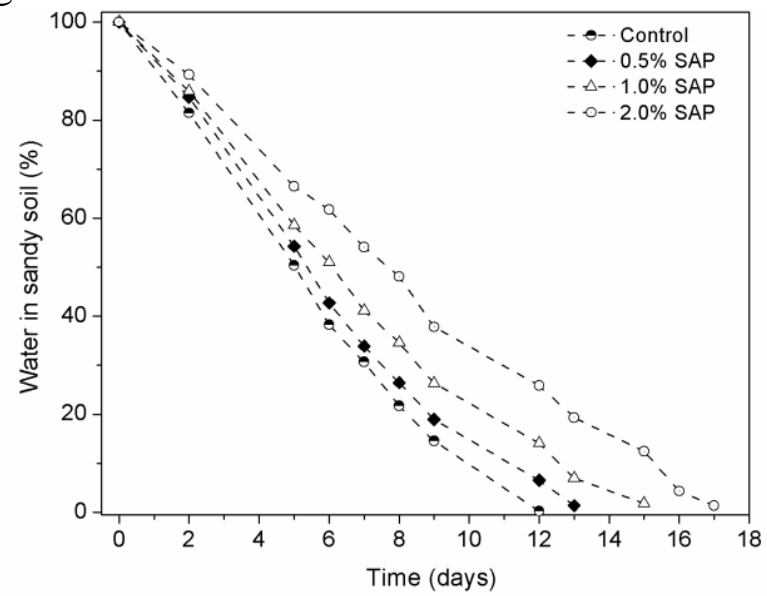

Figure 6: Moisture retention capacity in soil (control) and in mixtures soils with increasing amount of used SAP $(0.5,1$ and $2 \mathrm{wt} \%)$

\subsection{Seed Germination and Seedling Growth}

Seedling growth of both species, bean and pumpkin, was enhanced by the addition of used SAP in the sandy soil. Seed germination was considerably higher in $0.5-2.0 \%$ of SAP amended soils as compared to the control. As shown in Figure 7, the influence of used SAP on seed germination is evident; the controlled and sustained release of water allows plants to survive for several days without the need of further irrigation. As observed, the overall seed germination percentage of bean was slightly higher than pumpkin. The presence of SAP in the sandy soil drastically altered the height of the plants than of the not amended control with increments of 30, 127 and 399\%, respectively, with 0.5, 1 and 2\% of hydrogel in the case of bean (Phaseolus vulgaris L.), while for the pumpkin (C. pepo) the increases were 16, 59 and 178\%, corresponding to $0.5,1$ and $2 \%$ of hydrogel in soil. The increase in soil moisture retention and improvement in seed germination and seedling growth as a result of superabsorbent hydrogel amendments has been reported previously (Orikiriza et al., 2013). The quantity of this increment depends on the quantity of hydrophilic polymer used (Dorraji et al., 2010). The proposed superabsorbent polymer improved retention of soil moisture and also the availability of water for the plants, decreasing the rate of moisture loss, so a delay of approximately 20-23 days at the wilting point was observed. This delay in the wilting point reduces the water requirement of plants. The germination energy of the seeds in soil with incorporation of hydrophilic polymer was obviously higher and denser than that of the seeds in soil without SAPs (Table 1 and Table 2). This is likely because the SAPs not only can absorb large amounts of water but also have good water retention capability, which supplies enough water to promote plant growth. The root and shoot biomass weights of both species was generally higher in SAP amended soil. 


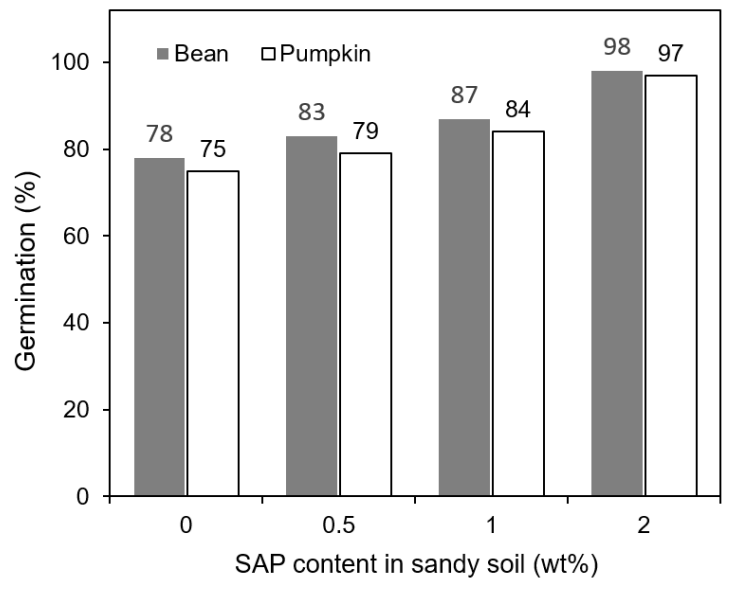

Figure 7: Sandy soil amended with used SAP and its effect in the seeds germination percentage

Table 1: Effect of used SAP-amended sandy soil on seedling growth (16 days) of bean (Phaseolus vulgaris L.)

\begin{tabular}{lllll}
\hline $\begin{array}{l}\text { SAP content } \\
\text { (wt } \%)\end{array}$ & $\begin{array}{l}\text { Height of } \\
\text { plant }(\mathbf{c m})\end{array}$ & $\begin{array}{l}\text { Length of the } \\
\text { root }(\mathbf{c m})\end{array}$ & $\begin{array}{l}\text { Weight } \\
\text { fresh plant }(\mathbf{g})\end{array}$ & $\begin{array}{l}\text { Dry weight } \\
\text { of plant }(\mathbf{g})\end{array}$ \\
\hline $0($ control) & $12.8 \pm 0.51$ & $9.2 \pm 0.65$ & 1.8716 & 0.2209 \\
0.5 & $16.7 \pm 0.71$ & $10.1 \pm 0.64$ & 2.1278 & 0.2311 \\
1.0 & $22.3 \pm 0.65$ & $10.8 \pm 81$ & 2.3165 & 0.2401 \\
2.0 & $28.4 \pm 0.76$ & $11.3 \pm 0.85$ & 2.5104 & 0.2503 \\
\hline
\end{tabular}

The results are means of three replicates; \pm , standard deviation (SD), with $\mathrm{P} \leq 0.05$ were considered to be statistically significant

Table 2: Effect of used SAP-amended sandy soil on seedling growth (16 days) of pumpkin (C.

реро)

\begin{tabular}{lllll}
\hline $\begin{array}{l}\text { SAP content } \\
\text { (wt\%) }\end{array}$ & $\begin{array}{l}\text { Height of the } \\
\text { plant }(\mathbf{c m})\end{array}$ & $\begin{array}{l}\text { Length of the } \\
\text { root }(\mathbf{c m})\end{array}$ & $\begin{array}{l}\text { Weight of } \\
\text { fresh plant }(\mathbf{g})\end{array}$ & $\begin{array}{l}\text { Dry weight } \\
\text { of plant }(\mathbf{g})\end{array}$ \\
\hline $0($ control) & $9.6 \pm 0.71$ & $9.4 \pm 0.68$ & 0.7650 & 0.0652 \\
0.5 & $11.9 \pm 0.74$ & $10.2 \pm 0.66$ & 1.1371 & 0.0858 \\
1.0 & $13.2 \pm 0.62$ & $11.7 \pm 0.71$ & 1.4138 & 0.1227 \\
2.0 & $16.5 \pm 0.83$ & $13.3 \pm 0.81$ & 1.6021 & 0.1533 \\
\hline
\end{tabular}

The results are means of three replicates; \pm , standard deviation (SD), with $P \leq 0.05$ were considered to be statistically significant

Increase in plant growth can also be attributed to the increase of nutrient retention in the hydrogel - soil mixture, even though no fertilizer was applied to the plants in the present study. The positive effect of the hydrogel usage for the plant survival and growth of the plants has been reported in various studies (Orikiriza et al., 2013). Although further investigations should be performed to assess the hydrogel degradation chemistry and kinetics in the soil, the preliminary results of this lab study show promise for the possible use of recycled hydrogels as water reservoir in agriculture. With regard to the hydrogel degradation, analyses that are currently in progress seem to suggest that the hydrogel degradation occurs over a period of approximately 6 months (Demitri et al., 2013), without significantly altering the soil chemistry. 


\section{Conclusions}

The superabsorbent polymer evaluated in this study showed the positive properties generally reported for others traditional hydrogels. The proposed SAP exhibited a high swelling ratio of $189 \mathrm{~g} \mathrm{~g}^{-1}$ of dry SAP. The results showed that, in salt solution, swelling ratio decreased with increasing ionic strength. The hydrogel exhibited a thermal and $\mathrm{pH}$ swelling behavior. Application of used superabsorbent polymer markedly improved retention capacity of soil for a longer time compared with control conditions. The use of the hydrogel from disposable diapers as water reservoir in the seed germination of bean and pumpkin in lab conditions was found to be advantageous and suitable for the sustained release of water to the soil and to the plant roots. These findings suggest that using SAP as soil conditioner will be useful for increased soil available water and consequently plant.

\section{Acknowledgements}

The authors would like to thank the support of the Tecnológico de Estudios Superiores de Jocotitlán in the development of this Research Project (PI201506).

\section{References}

[1] Akhter, J., Mahmood, K., Malik, K. A., Mardan, A., Ahmad, M. and Iqbal, M. M. (2004). "EFFECTS OF HYDROGEL AMENDMENT ON WATER STORAGE OF SANDY LOAM AND LOAM SOILS AND SEEDLING GROWTH OF BARLEY, WHEAT AND CHICKPEA." Plant, Soil and Environment, 50(10), 463-469.

[2] Cheng, W.-M., Hu, X.-M., Wang, D.-M. and Liu, G.-H. (2015). "PREPARATION AND CHARACTERISTICS OF CORN STRAW-Co-AMPS-Co-AA SUPERABSORBENT HYDROGEL.” Polymers, 7(11), 2431-2445. https://doi.org/10.3390/polym7111522.

[3] Colón, J., Mestre-Montserrat, M., Puig-Ventosa, I. and Sánchez, A. (2013). "PERFORMANCE OF COMPOSTABLE BABY USED DIAPERS IN THE COMPOSTING PROCESS WITH THE ORGANIC FRACTION OF MUNICIPAL SOLID WASTE.” Waste Management, 33(5), 10971103. https://doi.org/10.1016/j.wasman.2013.01.018.

[4] Colón, J., Ruggieri, L., Sánchez, A., González, A. and Puig, I. (2010). "POSSIBILITIES OF COMPOSTING DISPOSABLE DIAPERS WITH MUNICIPAL SOLID WASTES." Waste Management and Research, 29(3), 249-259. https://doi.org/10.1177/0734242X10364684.

[5] Cordella, M., Bauer, I., Lehmann, A., Schulz, M. and Wolf, O. (2015). "EVOLUTION OF DISPOSABLE BABY DIAPERS IN EUROPE: LIFE CYCLE ASSESSMENT OF ENVIRONMENTAL IMPACTS AND IDENTIFICATION OF KEY AREAS OF IMPROVEMENT." Journal of Cleaner Production, 95, 322-331. https://doi.org/10.1016/j.jclepro.2015.02.040.

[6] Demitri, C., Scalera, F., Madaghiele, M., Sannino, A. and Maffezzoli, A. (2013). "POTENTIAL OF CELLULOSE-BASED SUPERABSORBENT HYDROGELS AS WATER RESERVOIR IN AGRICULTURE." International Journal of Polymer Science, 2013, 1-6. https://doi.org/10.1155/2013/435073.

[7] Dorraji, S. S., Golchin, A. and Ahmadi, S. (2010). "THE EFFECTS OF HYDROPHILIC POLYMER AND SOIL SALINITY ON CORN GROWTH IN SANDY AND LOAMY SOILS." Clean - Soil, Air, Water, 38(7), 584-591. https://doi.org/10.1002/clen.201000017.

[8] EDANA. 2008. SUSTAINABILITY REPORT 2007-2008, ABSORBENT HYGIENE PRODUCTS, http://www.edana.org/docs/default-source/default-document-library/sustainabilityreport-2007-2008-absorbent-hygiene-products.pdf?sfvrsn=2 
[9] Eneji, A. E., Islam, R., An, P. and Amalu, U. C. (2013). "NITRATE RETENTION AND PHYSIOLOGICAL ADJUSTMENT OF MAIZE TO SOIL AMENDMENT WITH SUPERABSORBENT POLYMERS.” Journal of Cleaner Production, 52, 474-480. https://doi.org/10.1016/j.jclepro.2013.02.027.

[10] Espinosa-Valdemar, R. M., Sotelo-Navarro, P. X., Quecholac-Piña, X., Beltrán-Villavicencio, M., Ojeda-Benítez, S. and Vázquez-Morillas, A. (2014). "BIOLOGICAL RECYCLING OF USED BABY DIAPERS IN A SMALL-SCALE COMPOSTING SYSTEM." Resources, Conservation and Recycling, 87, 153-157. https://doi.org/10.1016/j.resconrec.2014.03.015.

[11] Espinosa-Valdemar, R.M., Turpin-Marion, S., Delfín-Alcalá, I. and Vazquez-Morillas, A. (2011). "DISPOSABLE DIAPERS BIODEGRADATION BY THE FUNGUS PLEUROTUS OSTREATUS." Waste Management, 31(8), 1683-1688. https://doi.org/doi:10.1016/j.wasman.2011.03.007.

[12] Espinosa-Valdemar, R.M., Vázquez-Morillas, A., Ojeda-Benítez, S., Arango-Escorcia, G., Cabrera-Elizalde, S., Quecholac-Piña, X., Velasco-Pérez, M. and Sotelo-Navarro, P.X. (2015). "ASSESSMENT OF GARDENING WASTES AS A CO-SUBSTRATE FOR DIAPERS DEGRADATION BY THE FUNGUS PLEUROTUS OSTREATUS.” Sustainability, 7, 2015, 6033-6045. https://doi.org/10.3390/su7056033.

[13] Essawy, H. A., Ghazy, M. B. M., El-hai, F. A. and Mohamed, M. F. (2016). "SUPERABSORBENT HYDROGELS VIA GRAFT POLYMERIZATION OF ACRYLIC ACID FROM CHITOSAN-CELLULOSE HYBRID AND THEIR POTENTIAL IN CONTROLLED RELEASE OF SOIL NUTRIENTS." International Journal of Biological Macromolecules, 89, 144-151. https://doi.org/10.1016/j.ijbiomac.2016.04.071.

[14] Gao, L., Wang, S. and Zhao, X. (2013). "SYNTHESIS AND CHARACTERIZATION OF AGRICULTURAL CONTROLLABLE HUMIC ACID SUPERABSORBENT." Journal of Environmental Sciences, 25(1), S69-S76. https://doi.org/10.1016/S1001-0742(14)60629-X.

[15] Gawande, N. and Mungray, A. A. (2015). "SUPERABSORBENT POLYMER (SAP) HYDROGELS FOR PROTEIN ENRICHMENT." Separation and Purification Technology. 150, 86-94. https://doi.org/10.1016/j.seppur.2015.04.024.

[16] Grimes, D. B. 2012. "SEPARATION OF MATERIALS COMPRISING SUPER ABSORBENT POLYMERS USING REDUCED WATER.” USA Patent, No. 8177151B2.

[17] Guilherme, M. R., Aouada, F. A., Fajardo, A. R., Martins, A. F., Paulino, A. T., Davi, M. F. T., Rubira, A. F. and Muniz, E. C. (2015). "SUPERABSORBENT HYDROGELS BASED ON POLYSACCHARIDES FOR APPLICATION IN AGRICULTURE AS SOIL CONDITIONER AND NUTRIENT CARRIER.” European Polymer Journal, 72, 365-385. https://doi.org/10.1016/j.eurpolymj.2015.04.017.

[18] Hong, S. H. and Lee, E. Y. (2016). "RESTORATION OF ERODED COASTAL SAND DUNES USING PLANT AND SOIL- CONDITIONER MIXTURE.” International Biodeterioration \& Biodegradation, 113, 161-168. https://doi.org/10.1016/j.ibiod.2016.04.021.

[19] Kosemund, K., Schlatter, H., Ochsenhirt, J. L., Krause, E. L., Marsman, D. S. and Erasala, G. N. (2009). "SAFETY EVALUATION OF SUPERABSORBENT BABY DIAPERS." Regulatory Toxicology and Pharmacology, 53(2), 81-89. https://doi.org/10.1016/j.yrtph.2008.10.005.

[20] Li, X., Li, Q., Su, Y., Yue, Q., Gao, B. and Su, Y. (2015). "A NOVEL WHEAT STRAW CELLULOSE-BASED SEMI-IPNs SUPERABSORBENT WITH INTEGRATION OF WATERRETAINING AND CONTROLLED-RELEASE FERTILIZERS.” Journal of the Taiwan Institute of Chemical Engineers, 55, 170-179. https://doi.org/10.1016/j.jtice.2015.04.022.

[21] Liao, R., Wu, W., Ren, S. and Yang, P. (2016). "EFFECTS OF SUPERABSORBENT POLYMERS ON THE HYDRAULIC PARAMETERS AND WATER RETENTION PROPERTIES OF SOIL." Journal of Nanomaterials, 2016, 1-11. https://doi.org/10.1155/2016/5403976. 
[22] Mirabella, N., Castellani, V. and Sala, S. (2013). "LIFE CYCLE ASSESSMENT OF BIOBASED PRODUCTS: A DISPOSABLE DIAPER CASE STUDY." International Journal of Life Cycle Assessment, 18(5), 1036-1047. https://doi.org/10.1007/s11367-013-0556-6.

[23] Ng, F. S.-F., Muthu, S. S., Li, Y. and Hui, P. C.-L. (2012). "A CRITICAL REVIEW ON LIFE CYCLE ASSESSMENT STUDIES OF DIAPERS.” Critical Reviews in Environmental Science and Technology, 43(16), 1795-1822. https://doi.org/10.1080/10643389.2012.671746.

[24] Orikiriza, L. J. B., Agaba, H., Eilu, G., Kabasa, J. D. and Worbes, M. (2013). "EFFECTS OF HYDROGELS ON TREE SEEDLING PERFORMANCE IN TEMPERATE SOILS BEFORE AND AFTER WATER STRESS." Journal of Environmental Protection, 4, 713-721. https://doi.org/10.4236/jep.2013.47082.

[25] Qiao, D., Liu, H., Yu, L., Bao, X., Simon, G. P., Petinakis, E. and Chen, L. (2016). "PREPARATION AND CHARACTERIZATION OF SLOW-RELEASE FERTILIZER ENCAPSULATED BY STARCH-BASED SUPERABSORBENT POLYMER.” Carbohydrate Polymers, 147, 146-154. http://doi.org/10.1016/j.carbpol.2016.04.010.

[26] Rosa, F. and Casquilho, M. (2012). "EFFECT OF SYNTHESIS PARAMETERS AND OF TEMPERATURE OF SWELLING ON WATER ABSORPTION BY A SUPERABSORBENT POLYMER." Fuel Processing Technology, 103, 174-177. https://doi.org/10.1016/j.fuproc.2011.09.004.

[27] Sannino, A., Demitri, C. and Madaghiele, M. (2009). "BIODEGRADABLE CELLULOSEBASED HYDROGELS: DESIGN AND APPLICATIONS.” Materials, 2, 353-373. https://doi.org/10.3390/ma2020353.

[28] SEMARNAT. 2012a. "GENERACIÓN ESTIMADA DE RESIDUOS SÓLIDOS URBANOS POR ENTIDAD FEDERATIVA (MILES DE TONELADAS).” Secretaría de Medio Ambiente y Recursos Naturales. http://apps1.semarnat.gob.mx/dgeia/compendio_2013/archivos/01_rsu/D3_RSM01_04.pdf

[29] SEMARNAT. 2012b. "DIAGNÓSTICO BÁSICO PARA LA GESTIÓN INTEGRAL DE LOS RESIDUOS." Secretaría de Medio Ambiente y Recursos Naturales, http://www.inecc.gob.mx/descargas/dgcenica/diagnostico_basico_extenso_2012.pdf

[30] Senna, A. M., Braga, J., Mauro, J. and Botaro, V. R. (2015). "SYNTHESIS, CHARACTERIZATION AND APPLICATION OF HYDROGEL DERIVED FROM CELLULOSE ACETATE AS A SUBSTRATE FOR SLOW-RELEASE NPK FERTILIZER AND WATER RETENTION IN SOIL.” Journal of Environmental Chemical Engineering, 3(2), 996-1002. https://doi.org/10.1016/j.jece.2015.03.008.

[31] Torrijos, M., Sousbie, P., Rouez, M., Lemunier, M., Lessard, Y., Galtier, L., Simao, A. and Steyer, J. P. (2014). "TREATMENT OF THE BIODEGRADABLE FRACTION OF USED DISPOSABLE DIAPERS BY CO-DIGESTION WITH WASTE ACTIVATED SLUDGE." Waste Management, 34(3), 669-675. https://doi.org/10.1016/j.wasman.2013.11.009.

[32] Zhang, X., Wang, X., Li, L., Zhang, S. and Wu, R. (2015). "PREPARATION AND SWELLING BEHAVIORS OF A HIGH TEMPERATURE RESISTANT SUPERABSORBENT USING TETRAALLYLAMMONIUM CHLORIDE AS CROSSLINKING AGENT." Reactive and Functional Polymers, 87, 15-21. https://doi.org/10.1016/j.reactfunctpolym.2014.12.006.

*Corresponding author.

E-mail address: r.sanchez@tesjo.edu.mx 